\title{
Response to Higashi et al.
}

\author{
Kuniaki Moriwaki ${ }^{1,2}$ and Kenji Kayashima ${ }^{1 *}$ (D)
}

To the Editor,

We thank Higashi et al. [1] for their expert opinions on our case report [2]. Herein, we address the concerns raised by them.

We administered neostigmine and atropine in our patient after insufficient sugammadex reversal, although we already used bibliographically sufficient doses of sugammadex (more than $1 \mathrm{mg} / \mathrm{kg}$ ) to eliminate the possibility of muscle relaxation rebound [3]. We agree with the opinion that intensive care and careful observation are necessary after neostigmine administration in such patients. We monitored the physical status of the patient for $24 \mathrm{~h}$ after extubation, although the data were not shown in the article [2]. Neostigmine reversal is associated with a dose-dependent increase in the risk of respiratory complications. However, proper use of neostigmine guided by neuromuscular transmission monitoring results can help eliminate postoperative respiratory complications associated with the use of the neuromuscular-blocking agent [4]. We are not certain about the differences in outcomes between sugammadex and neostigmine in such patients. Notably, sugammadex administration following laparoscopic sleeve gastrectomy has no advantages over neostigmine administration in terms of residual curarization and respiratory complications [5], and limited studies have investigated the effects of sugammadex on postoperative pulmonary outcomes [6].

Mild hypothermia possibly played a role in the prolongation of the neuromuscular blockade in our case, and the pharyngeal temperature was $34.8^{\circ} \mathrm{C}$ at the beginning of the operation and $35.4{ }^{\circ} \mathrm{C}$ just before extubation. A decrease in body temperature from 36.5 to $34.5^{\circ} \mathrm{C}$ increased the duration of action of vecuronium and rocuronium from 28 to $62 \mathrm{~min}$ and the spontaneous recovery time from 37 to $80 \mathrm{~min}$ [7]. An unexpected decrease in rocuronium elimination due to hypothermia possibly prolonged the neuromuscular blockade [7, 8].

* Correspondence: ken5ji5ka5ya5shi5ma@nifty.com

${ }^{1}$ Department of Anesthesia, Japan Community Health Care Organization,

Kyushu Hospital, 1-8-1 Kishinoura, Yahatanishi-ku, Kitakyushu, Fukuoka

806-8501, Japan

Full list of author information is available at the end of the article
However, under mild hypothermia, deep rocuroniuminduced neuromuscular blockade was safely reversed by sugammadex [9], and the efficacy of neostigmine was maintained [7].

Higashi et al. suggested that mechanisms underlying the residual blockade might be complicated and should be further investigated [1]. In addition to hypothermia, rocuronium and magnesium sulfate can affect acetylcholine release. Rocuronium, a non-depolarizing neuromuscular blocker, has pre-synaptic inhibitory effects on acetylcholine release [10]. Magnesium sulfate also shows a pre-synaptic effect by inhibiting acetylcholine release at motor nerve terminals, which may be responsible for the interaction of magnesium sulfate with vecuronium, a non-depolarizing neuromuscular blocker [11, 12]. Increased extracellular magnesium levels decrease the magnitude of acetylcholine-evoked responses and the single-channel conductance of nicotinic acetylcholine receptors at the mouse endplate [12]. Furthermore, magnesium sulfate shows concentrationdependent neuromuscular blocking effects in clinical settings [2].

Hypothermia, along with pre-synaptic inhibitory effects of magnesium sulfate and/or calcium channel antagonists, could have prolonged the neuromuscular blockade in our patient. We should bear in mind that non-depolarizing neuromuscular blockers and magnesium sulfate show pre-synaptic effects by inhibiting acetylcholine release to prolong neuromuscular blockade and cause insufficient reversal even after sugammadex administration. Careful observation after extubation is necessary for patients with prolonged neuromuscular blockade.

\section{Acknowledgments \\ We would like to thank Editage for English language editing.}

Authors' contributions

MK and KK wrote the manuscript and approved the final version.

Funding

No funding declared.

Availability of data and materials Not applicable. 
Ethics approval and consent to participate

Not applicable.

\section{Consent for publication}

Not applicable.

\section{Competing interests}

The authors declare that they have no competing interests.

\section{Author details}

'Department of Anesthesia, Japan Community Health Care Organization, Kyushu Hospital, 1-8-1 Kishinoura, Yahatanishi-ku, Kitakyushu, Fukuoka 806-8501, Japan. ${ }^{2}$ Present address: Department of Anesthesiology, University of Occupational and Environmental Health, Kitakyushu, Fukuoka 807-0804, Japan.

Received: 19 June 2019 Accepted: 31 July 2019

Published online: 13 August 2019

\section{References}

1. Higashi M, Tamura T, Adachi YU. Prolonged neuromuscular blockade by nondepolarizing neuromuscular blocking agents. JA Clin Rep. 2019;5:33.

2. Moriwaki K, Kayashima K. Prolonged neuromuscular blockade and insufficient reversal after sugammadex administration in cesarean section under general anesthesia: a case report. JA Clin Rep. 2019;5:28.

3. Eleveld DJ, Kuizenga K, Proost JH, Wierda JM. A temporary decrease in twitch response during reversal of rocuronium-induced muscle relaxation with a small dose of sugammadex. Anesth Analg. 2007;104:582-4.

4. McLean DJ, Diaz-Gil D, Farhan HN, Ladha KS, Kurth T, Eikermann M. Dose-dependent association between intermediate-acting neuromuscularblocking agents and postoperative respiratory complications. Anesthesiology. 2015;122:1201-13.

5. Ezri T, Evron S, Petrov I, Schachter P, Berlovitz Y, Shimonov M. Residual curarization and postoperative respiratory complications following laparoscopic sleeve gastrectomy. The effect of reversal agents: sugammadex vs. neostigmine. J Crit Care Med. 2015;1:61-7.

6. Park HP. Use of sugammadex in clinical practice. Korean J Anesthesiol. 2017; 70:377-8.

7. Heier T, Caldwell JE. Impact of hypothermia on the response to neuromuscular blocking drugs. Anesthesiology. 2006;104:1070-80.

8. Murata T, Kubodera T, Ohbayashi M, Murase K, Adachi YU, Matsuda N. Recurarization after sugammadex following a prolonged rocuronium infusion for induced hypothermia. Can J Anesth. 2013;60:508-9.

9. Lee HJ, Kim KS, Jeong JS, Kim KN, Lee BC. The influence of mild hypothermia on reversal of rocuronium-induced deep neuromuscular block with sugammadex. BMC Anesthesiol. 2015;15:7.

10. Takagi S, Adachi YU, Saubermann AJ, Vizi ES. Presynaptic inhibitory effects of rocuronium and $\mathrm{SZ} 1677$ on $[3 \mathrm{H}]$ acetylcholine release from the mouse hemidiaphragm preparation. Neurochem Int. 2002;40:655-9.

11. Wang $H$, Liang QS, Cheng LR, Li XH, Fu W, Dai WT, et al. Magnesium sulfate enhances non-depolarizing muscle relaxant vecuronium action at adult muscle-type nicotinic acetylcholine receptor in vitro. Acta Pharmacol Sin. 2011;32:1454-9.

12. Herroeder S, Schönherr ME, De Hert SG, Hollmann MW. Magnesium--essentials for anesthesiologists. Anesthesiology. 2011;114:971-93.

\section{Publisher's Note}

Springer Nature remains neutral with regard to jurisdictional claims in published maps and institutional affiliations.

\section{Submit your manuscript to a SpringerOpen ${ }^{\circ}$ journal and benefit from:}

- Convenient online submission

Rigorous peer review

- Open access: articles freely available online

High visibility within the field

Retaining the copyright to your article

Submit your next manuscript at $\boldsymbol{\nabla}$ springeropen.com 